\title{
Biotechnological

\section{Genetic characterization of native Bacillus thuringiensis strains isolated from Tamil Nadu, India}

\author{
D. Immanual Gilwax Prabhu* ${ }^{*}$, S. John Vennison ${ }^{2 *}$, P. Thirumalai Vasan ${ }^{3}$ and E. Kathiresan ${ }^{2}$ \\ ${ }^{1}$ Silkworm Breeding and Genetics, Central Tasar Research and Training Institute, Ranchi 835303, India \\ ${ }^{2}$ Department of Biotechnology, Anna University BIT-Campus, Tiruchirappalli 620024, India \\ ${ }^{3}$ Department of Biotechnology, Srimad Andavan College, Tiruchirappalli 620005, India
}

\begin{abstract}
B. thuringiensis is a crystalliferous bacteria used as a biocontrol agent against lepidopteran, dipteran, and coleopteran pests. Seventy eight Bacillus thuringiensis strains were isolated from 108 soil samples collected from Tamil Nadu, India. Phylogenetic relationship of $B$. thuringiensis isolates were evaluated based on PCR amplified fragment polymorphisms of flagellin genes (PCR-AFPF). The isolated B. thuringiensis strains comprised of 51.3\% of known biochemical types and 48.7\% of undescribed $B$. thuringiensis types. PCR-AFPF UPGMA dendrogram generated using Jaccard coefficient values showed two phylogenetic groups, group A and B comprised of I-XIII and XIV-XV clusters respectively. The present study concluded that $B$. thuringiensis isolates from Tamil Nadu have a high degree of genetic diversity and high rate of genetic exchange.
\end{abstract}

KEY WORDS: BACILLUS THURINGIENSIS, PCR-AFPF, GENETIC DIVERSITY, UPGMA DENDROGRAM

\section{INTRODUCTION}

Chemical insecticides that are currently used to control insect pests are extremely toxic to non-target organisms and many insects have developed resistance to different chemical pesticides, resulting in ineffective insect control programs. They are deleterious to the health of humans and animals, lead to cancer and immune system

\section{ARTICLE INFORMATION:}

Corresponding Authors: immanual.csb@gmail.com Received $13^{\text {th }}$ Sep, 2018

Accepted after revision $13^{\text {th }}$ Dec, 2018

BBRC Print ISSN: 0974-6455

Online ISSN: 2321-4007 CODEN: USA BBRCBA Thomson Reuters ISI ESC / Clarivate Analytics USA

Mono of Clarivate Analytics and Crossref Indexed Journal Mono of $C R$

NAAS Journal Score 2018: 4.31 SJIF 2017: 4.196

- A Society of Science and Nature Publication, Bhopal India 2018. All rights reserved.

Online Contents Available at: http//www.bbrc.in/

DOI: $10.21786 / \mathrm{bbrc} / 11.4 / 8$ disorders. In addition, chemical insecticides are recalcitrant, it accumulates in the environment and result in soil and water pollution (Devine and Furlong, 2007). The use of microbial insecticides is an alternative to chemical pesticides for insect control. Biological insecticides are mainly based on entomatopathogenic bacteria, Bacillus thuringiensis. 
B. thuringiensis is a member of a group of crystalliferous spore-forming gram-positive bacteria of the family Bacillaceae (Schnepf et al., 1998). This bacterium is able to produce proteinaceous parasporal crystals that exhibit specific insecticidal and nematicidal activities (Khyami-Horani et al., 1996; Carneiro et al., 1998; Al-Banna and Khyami-Horani, 2004). B. thuringiensis is commonly used as an organic biopesticide against lepidopteran, dipteran, and coleopteran insect pests (Schnepf et al., 1998). B. thuringiensis was first isolated from diseased silkworm (Bombyx mori) larvae (Ishiwata, 1901). Over the last five decades, B. thuringiensis has been developed as a microbial agent against lepidopteran pests (Carlton, 1990). In 1977, Goldberg and Margalit (1977) discovered a novel B. thuringiensis strain that expressed specific insecticidal properties against Diptera and another $B$. thuringiensis strain that targeted against Coleoptera was explored by Krieg et al. (1983). The success of various B. thuringiensis strains in controlling various insect pests has driven the establishment of several screening programmes for more novel $B$. thuringiensis strains. As a result, it is estimated that today, more than 50,000 B. thuringiensis strains are kept in various private and public bacterial collection centres (Sanchis et al. 1996).

There are many methods have been proposed to classify $B$. thuringiensis into sub-species level. The main classification of $B$. thuringiensis isolates was developed on the basis of H-flagellar antigens by de Barjac and Bonnefoi (1962). B. thuringiensis strains are classified into more than 82 serovars using $\mathrm{H}$-antigen method. However, there are two limitations with the H-classification for strains lacking parasporal inclusions and auto-agglutinated strains. Some $B$. cereus strains have antigens that cross-react with sera specific for $B$. thuringiensis H-serotypes (14) and such isolates may originate from older $B$. thuringiensis strains that have lost plasmid encoded crystals (Lecadet et al., 1999). These auto-agglutinated strains make up almost 3\% of the $B$. thuringiensis in the International Entomopathogenic Bacillus Center (IEBC) collection (Burges et al., 1982) at the Institute of Pasteur, Paris, France, but the H-classification is completely useless on these strains. In addition, a few $B$. thuringiensis strains, called non-motile strains such as B. thuringiensis var. wuhanensis, also escape H-serotyping (de Barjac and Frachon, 1990).

With the development of molecular biology, the classification and identification of bacteria has changed from traditional phenotypic to genotypic methods in recent decades. Pulsed field gel electrophoresis (PFGE), used for genotyping different bacterial strains of a specific species as in the case of $B$. thuringiensis strains (Gaviria and Priest, 2003). However, as PFGE requires special equipment and chemicals, it is not easy to per- form in many laboratories. Currently, molecular typing methods including Arbitrary Primer PCR technology (Brousseau et al., 1993), DNA reassociation measurements (Nakamura, 1994), ribosomal RNA gene restriction fragment length polymorphism (Priest et al., 1994; Akhurst et al., 1997), ribosomal RNA gene intergenic spacer sequences comparison (Bourque et al., 1995), DNA-colony hybridization and random amplified polymorphic DNA (RAPD) analysis (Hansen et al., 1998), have also been applied to a limited numbers of $B$. thuringiensis strains. To date, molecular techniques such as RAPD, RFLP, 16S rRNA probe, specific DNA probe, and ISR methods have not provided any great improvement over the H-classification method. Hence, in the present research, a faster, convenient and accurate method was followed to classify all subspecies of $B$. thuringiensis using PCR amplified fragment polymorphism of flagellin genes (PCR-AFPF).

\section{MATERIALS AND METHODS}

Soil collection and isolation of $B$. thuringiensis: Soil samples were collected from 108 locations in Tamil Nadu, India, that are very diverse in nature. The samples were collected from agricultural fields, high-altitude mountains, forests, grasslands and sewage. Soil samples were collected by scraping off surface material with a sterile spatula and then obtaining a $10 \mathrm{~g}$ sample from 1 or $2 \mathrm{~cm}$ below the surface. These samples were stored in sterile plastic bags at ambient temperature. One gram of soil was added to $10 \mathrm{ml}$ of Luria Broth, which was buffered with $0.25 \mathrm{M}$ sodium acetate (Travers et al., 1987). The mixture was shaken for $4 \mathrm{~h}$ at $250 \mathrm{rpm}$ in $30^{\circ} \mathrm{C}$, after incubation $1.5 \mathrm{ml}$ of sample mixture was taken and heat shocked at $80^{\circ} \mathrm{C}$ for $3 \mathrm{~min}$. $100 \mu \mathrm{l}$ of the suspension was plated on HiCrome ${ }^{\mathrm{TM}}$ Bacillus Agar supplemented with $10 \mu \mathrm{g} / \mathrm{ml}$ of polymyxin B. Colonies formed after overnight growth at $30^{\circ} \mathrm{C}$ were selected based on colour and colony morphology and the colony was transferred onto TCHA medium supplemented with $0.3 \%$ glucose. Cultures were allowed to grow and sporulate for $40 \mathrm{~h}$ at $30^{\circ} \mathrm{C}$ and the sporulated cultures were then checked for the presence of crystals, which was the criterion used to confirm the isolates as B. thuringiensis (Braun, 2000).

\section{Biochemical identification}

Fourteen biochemical tests such as acid production from glucose, arabinose, xylose, mannitol, mannose, salicin and sucrose; utilization of citrate and esculin; and production of protease, amylase, phospholipase C or lecithinase, and hemolysin were performed as described by Parry et al. (1983) to identify $B$. thuringiensis strains. For this study, only the results of the following four (the 
most relevant) biochemical tests are presented: esculin utilization, acid formation from salicin and sucrose, and lecithinase production (Martin and Travers, 1989). Based on these four biochemical tests the $B$. thuringiensis isolates classified into 16 biochemical types. The classification of $B$. thuringiensis strains in these groups was corresponding to the distribution obtained by additional tests.

\section{PCR-AFPF}

DNA C1000 thermal cycler (Bio-Rad) was used to carry out PCR amplification. Cells of different $B$. thuringiensis strains were inoculated on Luria-Bertani (LB) agar plates and incubated at $30^{\circ} \mathrm{C}$ for $12 \mathrm{~h}$. A loopful of cells was suspended in $100 \mu \mathrm{l}$ of nuclease free water in a $1.5-\mathrm{ml}$ Eppendorf tube. The cell suspension was frozen at $-70^{\circ} \mathrm{C}$ for $20 \mathrm{~min}$ and then boiled in water bath for $10 \mathrm{~min}$. The resultant lysate was centrifuged at 10,000 rpm for 10 min and five microliters of the supernatant was used as a source of DNA template. The AFPF primers used in this study was previously described by Yu et al. (2002) and are listed (Table 1). Primer was obtained from Eurofins MWG Operon, Germany. Each $50 \mu \mathrm{l}$ of PCR mixture contained $200 \mu \mathrm{M}$ deoxynucleotide triphosphates, $2 \mu \mathrm{M}$ $\mathrm{MgCl}_{2}, 12.5$ pmol per primer, and $2 \mathrm{U}$ of DreamTaq ${ }^{\mathrm{TM}}$ DNA polymerase (Fermentas). Amplification was performed using a single denaturation of $3 \mathrm{~min}$ at $94^{\circ} \mathrm{C}$ followed by a 35 cycle program, with each cycle consisting of denaturation at $94^{\circ} \mathrm{C}$ for $30 \mathrm{~s}$, annealing at $45^{\circ} \mathrm{C}$ for $30 \mathrm{~s}$, and extension at $72^{\circ} \mathrm{C}$ for $2 \mathrm{~min}$; the final extension step was $72^{\circ} \mathrm{C}$ for $10 \mathrm{~min}$. The PCR amplified products were detected by $1 \%$ agarose gel electrophoresis. The gels were scanned using AlphaImager gel documentation system.

\section{Data analysis}

Cluster analysis was used to examine genotypic relationships among the environmental $B$. thuringiensis isolates and it was performed using the AlphaView software, version 4.2 (Proteinsimple, CA). For data analysis, the profiles were converted into binary matrix. The computer cluster analysis was performed on the basis of calculation of the Jaccard Coefficient using unweighted pair group method with arithmetic mean (UPGMA) (Kumar et al., 1993).

\section{RESULTS AND DISCUSSION}

Isolation of $B$. thuringiensis from soil: Totally 108 soil samples were collected from different locations of 26 districts in Tamil Nadu, India. Soil samples were collected from cultivated fields (rice, sugarcane, coffee, tea, mango, papaya, cabbage, onion, tomato, coconut, and potato), natural vegetation (pine forests, shola forest,

\begin{tabular}{|c|c|}
\hline \multicolumn{2}{|c|}{$\begin{array}{l}\text { Table 1. Nucleotide sequences of primers used for } \\
\text { PCR-AFPF and multiplex PCR }\end{array}$} \\
\hline $\begin{array}{l}\text { Primer } \\
\text { Name }\end{array}$ & Sequence \\
\hline Fla5 & F - GGCGTCGACATGAGAATTAATACAAACATT \\
\hline Fla3 & R - CGCCTGCAGTTATTGTAATAATTTAGAAGCO \\
\hline
\end{tabular}

reserved forest, tropical evergreen forest, and grasslands) and sewage soils. The elevations of the places from which the samples collected were highly variable, ranging from sea level to 7,200 m above sea level. Among 82 soil samples, twenty six samples were collected from hilly regions (Ooty, Yercaud, Kolli hills, Palani, Kodaikanal, Sirumalai).

After acetate and polymyxin B selection, 97 of 108 soil sample yield colonies. Of these 97 samples, 70 (72\%) contained at least one crystal protein forming $B$. thuringiensis strains. From the 70 soil samples, $78 B$. thuringiensis strains were isolated and separated from 173 other spore forming organisms. Overall, this suggests that Tamil Nadu soils were enriched with $B$. thuringiensis.With the advent of a very selective procedure for separating $B$. thuringiensis spores from the spores of other soil microbes, $78 \mathrm{~B}$. thuringiensis strains have been isolated through acetate and polymyxin B selection. The distribution of $B$. thuringiensis in Tamil Nadu, is summarized (Table 2). In Tamil Nadu, the soil samples collected from districts such as, Vellore, Thanjavur and Theni were extremely rich in $B$. thuringiensis. Hundred percent of the soil sample contained $B$. thuringiensis. The soil sample collected from Krishnagiri, Nilgiris, Coimbatore, Trichy, Tirunelvelli and Kanyakumari had $75-80 \%$ of $B$. thuringiensis strains. On the other hand, soil samples collected from Ariyalur, Nagapatinam, Madurai, Virudhunagar and Tuticorin, only $25-33 \%$ of the soil samples contained $B$. thuringiensis strains.

Biochemical typing: The $B$. thuringiensis strains isolated from Tamil Nadu were identified and classified based on Martin and Travers (1989). In order to discriminate the isolated $B$. thuringiensis strains in to 16 biochemical types, four biochemical tests such as esculin utilization, acid formation from salicin and sucrose and lecithinase production were carried out and these were the most variable among $B$. thuringiensis isolates. $B$. thuringiensis isolates were given the biochemical type number based on the Martin and Travers (1989) and their occurrence in Tamil Nadu is also recorded (Table 3). Eventhough some of these types were differed by a single biochemical tests, these difference were more important. In this study $B$. thuringiensis subsp. kurstaki is widely available in the environment differed from leastly available $B$. thuringiensis subsp. galleriae by a single biochemical test, lecithinase production. Among 


\begin{tabular}{|l|l|l|l|}
\hline \multicolumn{5}{|l|}{ Table 2. Distribution of B. thuringiensis in soil } \\
\hline Districts & $\begin{array}{l}\text { No. of samples } \\
\text { examined }\end{array}$ & $\begin{array}{l}\text { \% of samples with B. } \\
\text { thuringiensis isolate } \\
\text { of samples) }\end{array}$ & $\begin{array}{l}\text { B. thuringiensis indexa } \\
\text { (no. of B. thuringiensis } \\
\text { isolates) }\end{array}$ \\
\hline Chennai & 4 & $50.0(2)$ & $0.22(2)$ \\
\hline Kanchipuram & 4 & $50.0(2)$ & $0.33(2)$ \\
\hline Vellore & 4 & $100.0(4)$ & $0.37(3)$ \\
\hline Krishnagiri & 4 & $75.0(3)$ & $0.28(4)$ \\
\hline Villupuram & 4 & $50.0(2)$ & $0.18(2)$ \\
\hline Nilgiris & 4 & $75.0(3)$ & $0.40(4)$ \\
\hline Erode & 4 & $50.0(2)$ & $0.22(2)$ \\
\hline Salem & 4 & $75.0(3)$ & $0.38(5)$ \\
\hline Ariyalur & 4 & $25.0(1)$ & $0.16(1)$ \\
\hline Perambulur & 4 & $50.0(2)$ & $0.25(2)$ \\
\hline Namakkal & 4 & $75.0(3)$ & $0.46(6)$ \\
\hline Coimbatore & 4 & $75.0(3)$ & $0.36(4)$ \\
\hline Tiruppur & 4 & $50.0(2)$ & $0.28(2)$ \\
\hline Karur & 4 & $75.0(3)$ & $0.25(2)$ \\
\hline Trichy & 4 & $75.0(3)$ & $0.27(3)$ \\
\hline Nagapattinam & 4 & $33.3(1)$ & $0.16(1)$ \\
\hline Tiruvarur & 4 & $66.6(2)$ & $0.40(2)$ \\
\hline Thanjavur & 4 & $100.0(4)$ & $0.30(4)$ \\
\hline Pudukottai & 4 & $75.0(3)$ & $0.33(2)$ \\
\hline Dindigul & 4 & $100.0(4)$ & $0.30(4)$ \\
\hline Theni & 4 & $100.0(4)$ & $0.33(4)$ \\
\hline Madurai & 4 & $75.0(2)$ & $0.44(4)$ \\
\hline Virudhunagar & 4 & $50.0(2)$ & $0.12(1)$ \\
\hline Tuticorin & 4 & $50.0(2)$ & $0.28(2)$ \\
\hline Tirunelveli & 4 & $75.0(3)$ & $0.36(4)$ \\
\hline Kanyakumari & 4 & $75.0(3)$ & $0.60(3)$ \\
\hline Ramanathapuram & 4 & $50.0(2)$ & $0.28(2)$ \\
\hline Total & 108 & $64.8(70)$ & $0.31(78)$ \\
\hline${ }^{2}$ B. thuringiensis index \\
colonies of all bacteria examined. & & \\
\hline
\end{tabular}

78 B. thuringiensis isolates, a maximum of 12 (15.4\%) $B$. thuringiensis subsp. kurstaki strains were isolated from different soil samples. B. thuringiensis subsp. israelensis was not present in any of the samples. The biochemical types $9,10,11,13,15$ and 16 made up a cluster of strains which accounted for $48.7 \%$ of all environmental isolates. The biochemical type of each isolates is recorded (Table 3). The results are similar to the study reported by Martin and Travers (1989), but they have got more isolates of six undescribed $B$. thuringiensis biochemical types (52\%) than the known biochemical types (48\%).

The widely accepted and well established typing method for B. thuringiensis strains is serotyping. But the current serotyping system is not suitable for auto agglutinated strains, non-motile strains and strains lacking a parasporal inclusion body. From the point of bacterial systematic classification, serotyping is a phenotypic system which cannot reveal phylogenetic relationships among the strains (Joung and Côté, 2001).

Analysis of AFPF-PCR amplified products: PCR was performed using cell lysate as DNA template with Fla5 and Fla3 primers. AFPF-PCR yielded multiple distinct DNA products of sizes ranging from approximately 100 to 2000bp of more than 300 fragments from 78 B. thuringiensis strains (Fig. 1). All B. thuringiensis isolates differed from one another in the specific amplified patterns of the PCR products, which correspond to the presence of flagellin gene sequence. In these isolates the major number of bands was observed at the size of 100, 225 and 425bp. Most of the amplified products were observed 


\begin{tabular}{|c|c|c|c|c|c|}
\hline \multirow[b]{2}{*}{ Biochemical Type } & \multicolumn{4}{|c|}{ Biochemical test result ${ }^{b}$} & \multirow{2}{*}{$\begin{array}{l}\text { B. thuringiensis } \\
\text { isolates in Tamil } \\
\text { Nadu, India (\%) }\end{array}$} \\
\hline & Esculin & Salicin & Lecithinase & Sucrose & \\
\hline 1 (thuringiensis) & + & + & + & + & $4(5.1)$ \\
\hline 2 (kurstaki) & + & + & + & - & $12(15.4)$ \\
\hline 3 (indiana) & + & + & - & + & $3(3.8)$ \\
\hline 4 (galleriae) & + & + & - & - & $1(1.3)$ \\
\hline $5(s o t t o)$ & + & - & + & + & $3(3.9)$ \\
\hline 6 (dendrolimus) & + & - & + & - & $11(14.1)$ \\
\hline 7 (morrisoni) & + & - & - & + & $3(3.8)$ \\
\hline 8 (darmstadiensis) & + & - & - & - & $2(2.6)$ \\
\hline 9 (Biochemical type 9) & - & + & + & + & $4(5.1)$ \\
\hline 10 (Biochemical type 10) & - & + & + & - & $6(7.7)$ \\
\hline 11 (Biochemical type 11) & - & + & - & + & $1(1.3)$ \\
\hline 12 (ostriniae) & - & + & - & - & $1(1.3)$ \\
\hline 13 (Biochemical type 13) & - & - & + & + & $9(11.5)$ \\
\hline 14 (israelensis) & - & - & + & - & $0(0)$ \\
\hline 15 (Biochemical type 15) & - & - & - & + & $10(12.8)$ \\
\hline 16 (Biochemical type 16) & - & - & - & - & $8(10.3)$ \\
\hline \multicolumn{5}{|l|}{ Total } & 78 \\
\hline
\end{tabular}

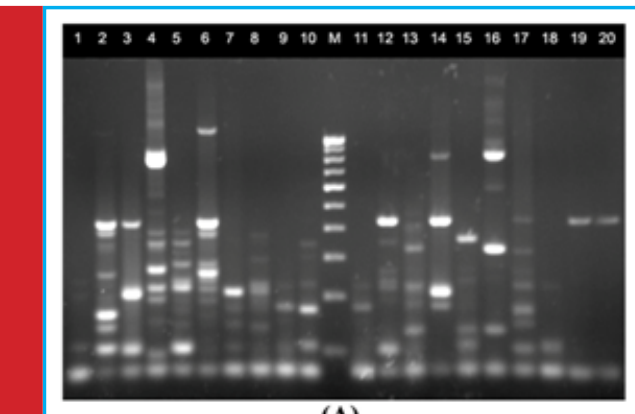

(A)
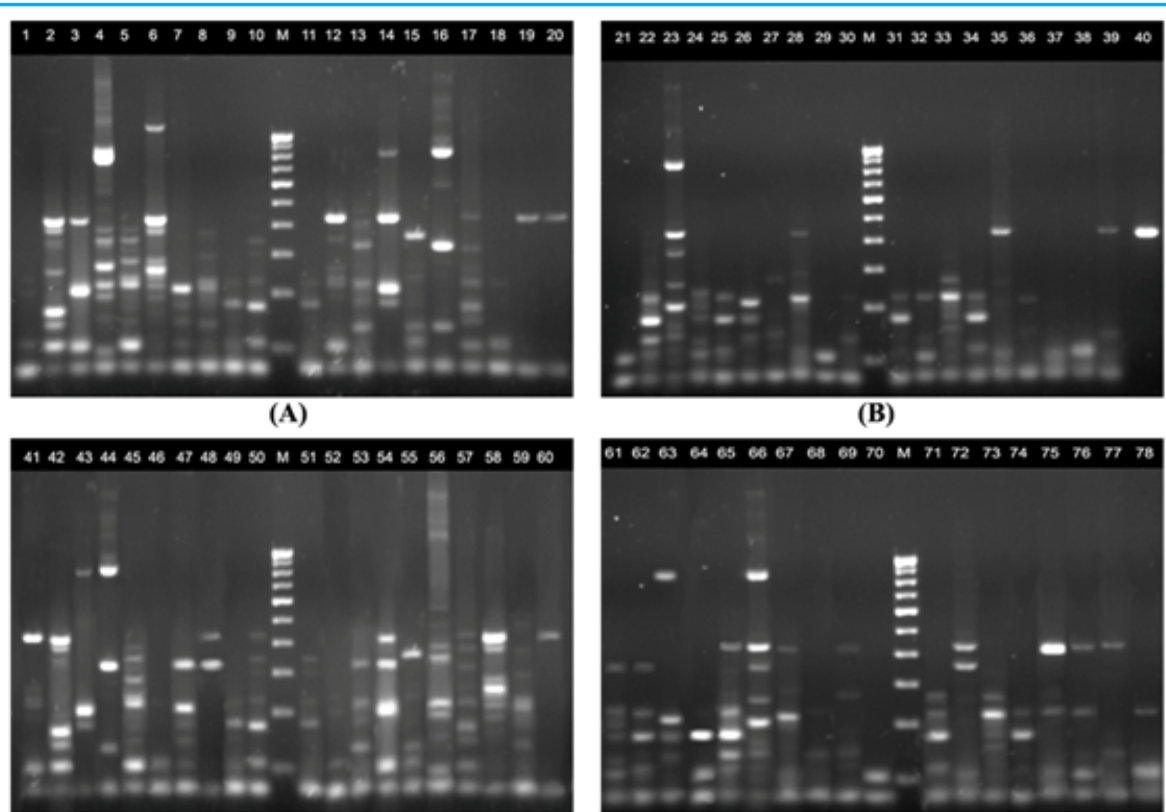

(C)

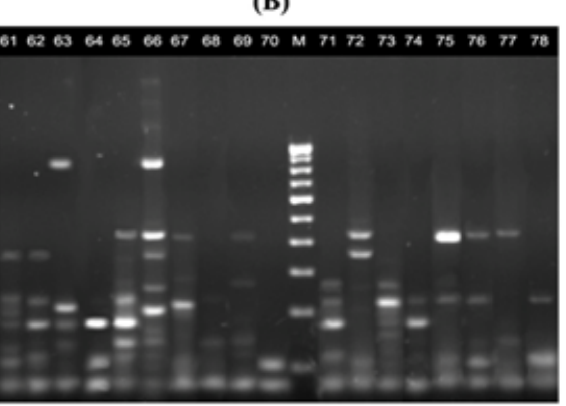

(D)

FIGURE 1. PCR-AFPR fingerprint patterns of environmental isolates of Bacillus thuringiensis. (A) Bacillus thuringiensis Tamil Nadu (BTTN) isolates BTTN01 - BTTN20; (B) BTTN20 - BTTN40; (C) BTTN41 - BTTN60; (D) BTTN61 - BTTN78. Lane M, 100bp ladder. 


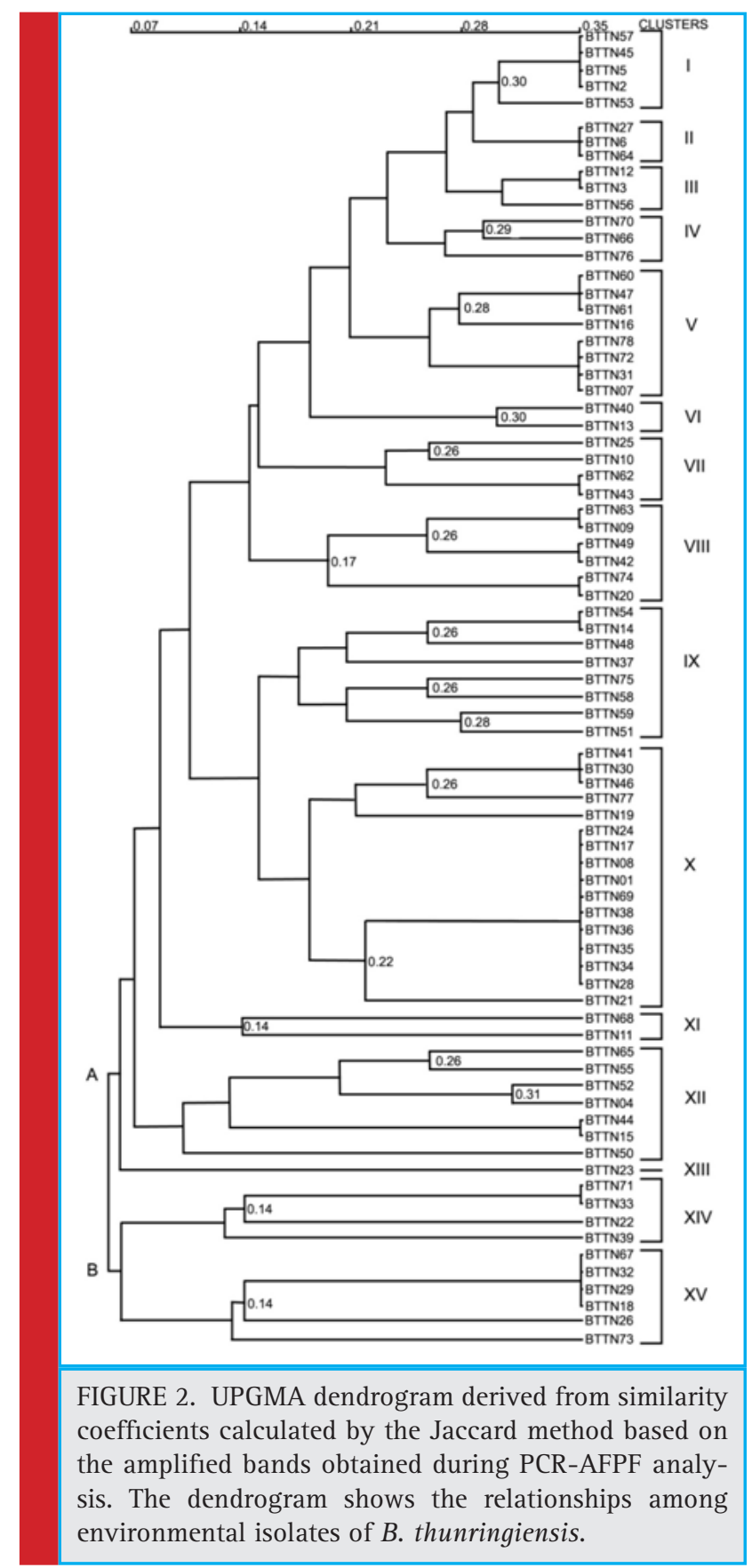

between 100 to $1000 \mathrm{bp}$ and only few of the isolates (BTTN4, 6, 16, 23, 44, 56 and 66) contained fragments more than $1000 \mathrm{bp}$. Only a distinct single product with a size of about 100 or $425 \mathrm{bp}$ was obtained in the strains such as, BTTN19, 20, 21, 29, 38, 40, 60 and 70. The maximum of 12 to 14 bands ranged from sizes $100-2000 \mathrm{bp}$ were observed in BTTN4, 23, 56 and 66.

PCR-AFPF is a preliminary attempt of Yu et al. (2002) to classify the subspecies of $B$. thuringiensis obtained from the Institute of Pasteur, France and in the present study this tool is used to discriminate between the $B$. thuringiensis serovars isolated from the environment. The chromosome of all $B$. thuringiensis strains contain flagellin gene and it was present even in their closely related species $B$. cereus and $B$. anthracis. Its PCR amplification pattern analysis is not subjected to any limitation associated with the $B$. thuringiensis serotyping system. The phyolgenetic analysis of $B$. thuringiensis using PCR-AFPF would be more accurate, than previously described molecular classification methods such as RAPD, RFLP, 16s rRNA probe, specific DNA probe, and ISR (Yu et al., 2002). The AFPF primers recognises differences in the prevalence and positions of annealing sites in the genome producing sets of fragments that are considered to reflect the genomic composition of the strain, therefore it gives a good opportunity to detect biodiversity of a group of isolates.

Phylogenetic analysis using UPGMA method: The genetic distance, Jaccard coefficient values were calculated from amplified bands and the values were ranged from 0.07 to 0.035 (Fig. 2). An unweighed pair group method with average (UPGMA) dendrogram was constructed using the Jaccard coefficient. In UPGMA dendrogram, the $B$. thuringiensis isolates were divided into 2 groups, group A and B. Group A was further classified into 13 clusters (I - XIII), which comprised of $68 B$. thuringiensis isolates and remaining 10 strains, BTTN71, 33, 22, 39, 67, 32, 29, 18, 26 and 73 were categorized in cluster XIV and XV and these two clusters were grouped under group B. Among I to XV clusters, cluster I, X, XII and XIV contains the mixture of different $B$. thuringiensis biochemical types and rest of the 11 clusters contains any one of the biochemical types. The maximum of $20.5 \%$ of $B$. thuringiensis isolates were classified under cluster $X$ and it comprised $6.25 \%$ of biochemical type 9, 25\% of B. thuringiensis subsp. kurstaki and $68.75 \%$ of $B$. thuringiensis subsp. dendrolimus. At the least of cluster XIII contained only one biochemical type 9 strain and this type showed more degree of variations in their band pattern among their biochemical type and these four biochemical type 9 strains were characterized under 3 clusters (X, XI and XIII). This confirmation of variation or intermixing of biochemical type 9 within the clusters suggests that the specific phenotypes were acquired after the ancestors to each of the clusters were formed. The study supports the idea that horizontal gene transfer of plasmid is an important factor in defining the phenotypes of biochemical type 9 isolates evolved along perceptible large evolutionary distances to give rise to different clusters.

The study of Katara et al. (2012) demonstrated that molecular typing and diversity analysis of $B$. thuringiensis has enormous importance for discrimination of strains isolated from different sources. They distinguished 113 native $B$. thuringiensis strains isolated from various 
locations in India using REP-PCR and ERIC-PCR. They explored that the $B$. thuringiensis isolates collected from diverse habitats in India had a high degree of genetic diversity. Similar to them, the $B$. thuringiensis strains which were isolated from Tamil Nadu showed diverse range of patterns and high level of genetic diversity.

\section{CONCLUSION}

Through the present study, it is suggested that the association between $B$. thuringiensis and insects is not obligative. $B$. thuringiensis was omnipresent when compared to other bacterial strains and based on the nutrient requirements the growth turnover is possible. There is no need that the population of $B$. thuringiensis has to be more in the soil samples with high levels of insect activity because several soil samples had been collected from the mosquito breeding regions but no $B$. thuringiensis isolates had shown any degree of mosquito larvicidal activity. Finally, the genetic heterogeneity were analysed in the B. thuringiensis strains isolated from Tamil Nadu using AFPF-PCR. This technique could be used for the separation of novel $B$. thuringiensis isolates from the environment.

\section{REFERENCES}

Akhurst, R.J., Lyness, E.W., Zhang, Q.Y., Cooper, D.J., Pinnock, D.E. (1997) A 16S rRNA oligonucleotide probe for identification of Bacillus thuringiensis isolates from sheep fleece. J. Invertebr. Pathol. 69, 24-31.

Al-Banna, L., Khyami-Horani, H. (2004) Nematicidal activity of two Jordanian strains of Bacillus thuringiensis on root-knot nematodes. Nematol. Mediterr. 32, 41-45.

Bourque, S.N., Valero, J.R., Lavoie, M.C., LeÂvesque, R.C. (1995) Comparative analysis of the $16 \mathrm{~S}$ to $23 \mathrm{~S}$ ribosomal intergenic spacer sequences of Bacillus thuringiensis strains and subspecies and of closely related species. Appl. Environ. Microbiol. 61, 1623-1626.

Braun, S. (2000) Production of Bacillus thuringiensis insecticides for experimental uses. In: Navon, A., Ascher, K.R.S. (Eds.), Bioassays of Entomopathogenic Microbes and Nematodes, CABI, London, UK, pp. 49-72.

Brousseau, R., Saint-Onge, A., PreÂfontaine, G., Masson, L. And Cabana, J. (1993) Arbitrary primer polymerase chain reaction, a powerful method to identify Bacillus thuringiensis serovars and strains. Appl. Environ. Microbiol. 59, 114-119.

Burges, H.D., Aizawai, A., Dulmage, H.T., de Barjac, H. (1982) Numbering of the H-serotypes of Bacillus thuringiensis. J. Invertebr. Pathol. 40, 419.

Carlton, B. (1990) Alternatives for suppressing agricultural pests and diseases. In: Baker, R.R., Dunn, P.E., Liss, A.R. (Eds.), New Directions in Biological Control. New York: American Elsevier Publishing Co., pp. 419-434.
Carneiro, R.M.D.G., de Souza, I.S., Belarmino, L.C. (1998) Nematicidal activity of Bacillus spp. strains on juveniles of Meloidogyne javanica. Nematol. Brasileira. 22, 12-21.

de Barjac, H., Bonnefoi, A. (1962) Essai de classification biochimique et serologique de 24 souches de Bacillus du type $B$. thuringiensis. Entomophaga 7, 5-31

de Barjac, H., Frachon, E. (1990) Classification of Bacillus thuringiensis strains. Entomophaga 35, 233-240

Devine, G.J., Furlong, M.J. (2007) Insecticide use: contexts and ecological consequences. Agric. Human Values 24, 281-306.

Gaviria, R.A.M., Priest, F.G. (2003) Pulsed field gel electrophoresis of chromosomal DNA reveals a clonal population structure to Bacillus thuringiensis that relates in general to crystal protein gene content. FEMS Microbiol. Lett. 223, 61- 66.

Goldberg, L.Y., Margalit, J. (1977) A bacterial spore demonstrating rapid larvicidal activity against Anopheles sergentii, Uranotaenia unguiculata, Culex univittatus, Aedes aegypti and Culex pipiens. Mosq. News 37, 355-358.

Hansen, B., Damgaard, P.H., Eilenberg, J., Pedersen, J.C. (1998) Molecular and phenotypic characterization of Bacillus thuringiensis isolated from leaves and insects. J. Invertebr. Pathol. 71, 106-114.

Ishiwata, S. (1901) On a kind of severe flacherue (sotto disease). Dainihan Sanshi Kaiho 114, 1-5.

Joung, K.B., Côté, J.C. (2001) Phylogenetic analysis of Bacillus thuringiensis serovars based on 16S rRNA gene restriction fragment length polymorphisms. J. Appl. Microbiol. 90, 115-22.

Katara, J., Deshmukh, R., Singh, N.K., Kaur, S. (2012) Molecular typing of native Bacillus thuringiensis isolates from diverse habitats in India using REP-PCR and ERIC-PCR analysis. J. Gen. Appl. Microbiol. 58, 83-94.

Khyami-Horani, H., Katbeh-Bader, A., Mohsen, Z.H. (1996) Mosquito larvicidal toxicity of endospore-forming bacilli isolated in Jordan. Dirasat. Med. Biol. Sci. 23,140-144

Krieg, A., Huger, A.M., Langenbruch, G.A., Schnetter, W. (1983) Bacillus thuringiensis var. tenebrionis, a new pathotype effective against larvae of Coleoptera. Zeitschrift für Angewandte Entomologie 96, 500 - 508.

Kumar, S., Tamura, K., Nei, M. (1993) MEGA: Molecular Evolutionary Genetics Analysis, version 1.0 (user manual), The Pennsylvania State University, University Park, PA 16802, USA.

Lecadet, M.M., Frachon, E., Dumanoir, V.C., Ripouteau, H., Hamon, S., Laurent, P., Thiery, I. (1999) Updating the H-antigen classification of Bacillus thuringiensis. J. Appl. Microbiol. 86, 660-672.

Martin, P.A.W., Travers, R.S. (1989) Worldwide Abundance and Distribution of Bacillus thuringiensis Isolates. Appl. Environ. Microbiol., 55, 2437-2442.

Nakamura, L.K. (1994) DNA relatedness among Bacillus thuringiensis serovars. Int. J. Syst. Bacteriol. 44, 125-129.

Parry, J.M., Turnball, P.C.B., Gibson, J.R. (1983) A Colour Atlas of Bacillus Species. Wolfe Medical Publications, Ltd., London. United Kingdom. 
Priest, F.G., Kaji, D.A., Rosato, Y.B., Canhos, V.P. (1994) Characterization of Bacillus thuringiensis and related bacteria by ribosomal RNA gene restriction fragment length polymorphisms. Microbiology 140, 1015-1022.

Sanchis, V., Chaufaux, J., Lereclus, D. (1996) Amélioration biotechnologique de Bacillus thuringiensis: les enjeux et les risques. Annales de l'Institut Pasteur/Actualités 7, 271-284.

Schnepf, E., Crickmore, N., Van Rie, J., Lereclus, D., Baum, J., Feitelson, J., Zeigler, D.R., Dean, D.H. (1998) Bacillus thuring- iensis and its pesticidal crystal proteins. Microbiol. Mol. Biol. Rev. 62, 775-806.

Travers, R.S., Martin, P.A.W., Reichelderfer, C.F. (1987) Selective process for efficient isolation of soil Bacillus sp. Appl. Environ. Microbiol. 53, 1263-1266.

Yu, J., Tan, L., Liu, Y., Pang, Y. (2002) Phylogenetic analysis of Bacillus thuringiensis based on PCR amplified fragment polymorphisms of flagellin genes. Curr. Microbiol. 45, 13943. 